\title{
The Influence of Competence and Independence to Work Effectiveness of Auditor at Regional Inspectorate of Gorontalo Province
}

\author{
Novianty Talib, Rosman Ilato, Ismet Sulila \\ Program Studi Magister Ilmu Administrasi \\ Universitas Negeri Gorontalo 2020
}

\begin{abstract}
The research objective was to find out the influence of competence and independence on the work effectiveness of auditor at Regional Inspectorate of Gorontalo Province either partially or simultaneously. The approach used in this research was quantitative. The research method used expost facto. The research design applied causality. The technique of data analysis used multiple regression. The research finding showed that (1) competence of auditor had a positive and significant influence on the work effectiveness of auditor at Regional Inspectorate of Gorontalo Province by the determinant value of $23,50 \%$. The meaning of the positive coefficient indicated that the higher the competence of auditor, the more effective work result of auditor at Regional Inspectorate of Gorontalo Province. (2) Independence of auditor had a positive and significant influence on the work effectiveness of auditor at Regional Inspectorate of Gorontalo Province by determinant value of 56,60\%. The meaning of positive coefficient indicated that the more independent of auditor in doing inspection and functional supervision function, the more optimum work effectiveness of auditor at Regional Inspectorate of Gorontalo Province. (3) The competence and independence of auditor, simultaneously, had a significant influence on the work effectiveness of auditor at Regional Inspectorate of Gorontalo Province by determinant value of $61,70 \%$. Meanwhile, the rest $38,30 \%$ could be explained by other variables such as auditor education, auditor integrity, auditor work motivation, work discipline, and auditor professionalism attitude.
\end{abstract}

Keywords: Work Effectiveness, Auditor Competence, Auditor Independence 
PENDAHULUAN

Bagi seorang auditor efektivitas kerja

suatu keadaan yang sangat penting dan urgensinya tinggi karena menjadi suatu keadaan dimana auditor mampu untuk melakukan dan menyelesaikan pekerjaannya sesuai dengan waktu dan kuantitas serta kualitas yang telah ditetapkan. Terkait dengan efektivitas kerja auditor dalam melakukan pemeriksaan dan pengawasan maka penelitian ini difokuskan pada Inspektorat Daerah Provinsi Gorontalo. Pemilihan lokasi ini didasarkan pada temuan lapangan bahwa terdapat pegawai atau auditor yang hasil pekerjaanya sudah baik namun masih perlu untuk ditingkatkan terutama dalam aspek efektivitas kerja.

Efektivitas kerja dari seorang auditor akan baik jika hal ini dapat terpenuhi sesuai dengan kriteria pekerjaan efektif yakni harus mencapai $\geq 90 \%$ sebagaimana menurut Mardiasmo (2012: 96). Auditor internal di Inspektorat Daerah Provinsi Gorontalo telah memiliki hasil kerja yang efektif ditinjau dari kualitas kerja dan kuantitas kerja yang dalam hal ini menunjukan bahwa auditor mampu menyelesaikan pekerjaanya meskipun dengan kuantitas yang banyak dan dengan hasil yang baik. Sementara itu untuk pemanfaatan waktu masih menjadi kendala auditor internal karena dominannya auditor tidak mampu mencapai target waktu yang telah ditentukan oleh pimpinan. Kemudian untuk pengembangan SDM cenderung mengalami peningkatan namun masih kurang optimal.

Sementara itu, laporan LKPD dimana Provinsi Gorontalo telah mencapai opini yang sangat baik yakni wajar tanpa pengecualian (WTP) namun masih ada saja temuan BPK, hal ini yang menandakan bahwa auditor internal Provinsi Gorontalo masih perlu meningkatkan kinerja dan efektivitas kerjanya agar LKPD Provinsi Gorontalo menghasilkan laporan dengan hasil yang sangat baik dan sudah tidak ada lagi hal-hal krusial yang menjadi sorotan BPK. Kemudian hal ini diperkuat dengan laporan pada IHPS BPK ditemukan bahwa setiap tahunnya masih terdapat masalah pada aset di Provinsi Gorontalo yang padahal hal ini seharusnya diatur lebih dulu oleh auditor internal pemerintahan di Provinsi Gorontalo.

Kemudian permasalahan juga pada barang milik negara, dimana serah terima BMN yang menjadi objek Penyertaan Modal Pemerintah Pusat dilaksanakan setelah Peraturan Pemerintah mengenai Penyertaan Modal Pemerintah Pusat ditetapkan. Mekanisme dan Penerapan PMK atau Tata Cara Pelaksanaan Pemindahtanganan Barang Milik Negara memang telah diatur dan sangat membutuhkan suatu penilaian yang baik karena dengan penilaian yang sesuai maka dampaknya pada pencatatan akuntansi. Apabila barang yang ada dinilai atau dilakukan penilaian oleh tim aprasial yang 
hasilnya tidak sesuai maka pengakuan akuntansinya juga akan bermasalah.

Berbagai hal penting dalam menghasilkan audit yang berkualitas atau dalam hal ini efektivitas kerja yang baik dalam menghasilkan audit yang optimal yakni kompetensi auditor. Menurut Harhinto (2004: 35) bahwa kompetensi sendiri dapat dipahami sebagai sebuah kombinasi antara ketrampilan (skill), atribut personal, dan pengetahuan (knowledge) yang tercermin melalui perilaku kinerja (job behavior) yang dapat diamati, diukur dan dievaluasi. Menurut Setyaningrum dan Kuntadi (2019) bahwa kompetensi, pekerjaan audit dan komunikasi berpengaruh positif terhadap efektivitas audit internal. Hal ini memberikan implikasi bahwa auditor harus dibekali dengan kompetensi teknis audit maupun kompetensi non-teknis terkait bidang yang diaudit.

Terkait dengan kompetensi pada dasarnya auditor di Inspektorat Daerah Provinsi Gorontalo telah memiliki pengetahuan dan keterampilan yang baik namun dalam hal ini terdapat hal-hal yang masih kurang terutama dalam kemampuan teknis serta kepatuhan pada kegiatan audit yang harus dilakukan sesuai dengan perencanaan. Selain itu pengembangan kompetensi juga masih perlu dilakukan pada seluruh pegawai terutama kompetensi spiritual dan sosial agar auditor lebih mampu untuk melakukan pemeriksaan secara independen dan memiliki integritas yang tinggi serta lebih mampu dalam melaksanakan pekerjaan yang setiap harinya terus meningkat bahkan pada pengawasan hingga ke tingkat pemerintah desa.

Faktor lain yang tidak kalah penting yakni independensi dari auditor. Christiawan (2003: 86) menyatakan independensi merupakan suatu tindakan baik sikap perbuatan atau mental auditor sepanjang pelaksanaan audit, dimana seorang auditor harus bisa memposisikan dirinya untuk tidak memihak oleh pihak-pihak yang berkepentingan terhadap hasil auditnya. Bohawia,et.,al (2015) mengatakan bahwa independensi atau komitmen auditor terhadap organisasi adalah bentuk loyalitas terhadap organisasi auditor agar mampu lebih bijak dalam mengambil keputusan. Arens, dkk (2008: 111) juga mengungkapkan bahwa dengan adanya sikap independensi maka masyarakat akan lebih percaya terhadap hasil yang diperoleh atau ditemukan pada saat pemeriksaan audit dan secara langsung akan mempengaruhi tehadap hasil kinerja yang dihasilkannya.

Independensi dari auditor di Inspektorat Daerah Provinsi Gorontalo pada dasarnya sudah bagus karena rutinnya pendidikan dan pelatihan namun karena adanya mutasi antar bidang membuat auditor harus beradaptasi kembali dengan bidang yang baru. Sedangkan dari segi independensi dekatnya hubungan interpersonal, baik 
$\begin{array}{cccc}\text { hubungan } & \text { kekerabatan } & \text { atau relasi } \\ \text { kepentingan } & \text { lainnya } & \text { mempengaruhi }\end{array}$ independensi aparat Inspektorat Daerah Provinsi Gorontalo. Provinsi Gorontalo.

Adanya permasalahan di atas merupakan fenomena menarik untuk diteliti secara ilmiah. Berdasarkan uraian latar belakang di atas, maka peneliti tertarik untuk melakukan sebuah penelitian ilmiah dengan judul "Pengaruh Kompetensi dan Independensi Terhadap Efektivitas kerja Auditor Di Inspektorat Daerah Provinsi Gorontalo".

\section{METODOLOGI PENELITIAN}

Tempat yang dipilih sebagai lokasi penelitan sesuai dengan judul penelitian dan sangat relevan dengan permasalahan yang diajukan adalah Inspektorat Daerah Provinsi Gorontalo. Waktu pelaksanaan penelitian di butuhkan 4 bulan yaitu sejak bulan November 2019 sampai dengan Maret 2020.

Untuk memudahkan dalam pengujian hipotesis penelitian, maka peneliti menetapkan variabel penelitian yang disajikan dalam tabel definisi operasional variabel sebagai berikut:

\begin{tabular}{|c|c|c|}
\hline Variabel & Indikator & Skala \\
\hline $\begin{array}{l}\text { Kompetensi } \\
\text { Auditor }\end{array}$ & $\begin{array}{l}\text { 1. Komponen pengetahuan. } \\
\text { 2. Ciri-ciri psikologis } \\
\text { 3. Strategi penentuan } \\
\text { keputusan } \\
\text { 4. Kemampuan berpikir } \\
\text { 5. Analisa tugas. }\end{array}$ & Ordinal \\
\hline $\begin{array}{l}\text { Independensi } \\
\text { Auditor }\end{array}$ & $\begin{array}{lll}\text { 1. } & \begin{array}{l}\text { Independen } \\
\text { gangguan pribadi }\end{array} & \text { terhadap } \\
\text { 2. } & \text { Independen } \\
\text { gangguan ektern } & \text { terhadap } \\
\text { 3. } & \begin{array}{l}\text { Independen } \\
\text { gangguan organisasi }\end{array} \\
\end{array}$ & Ordinal \\
\hline $\begin{array}{c}\text { Efektivitas } \\
\text { Kerja Auditor }\end{array}$ & $\begin{array}{ll}\text { 1. } & \text { Kualitas kerja } \\
\text { 2. } & \text { Kuantitas kerja } \\
\text { 3. } & \text { Pemanfaatan waktu } \\
\text { 4. } & \text { Peningkatan kualitas SDM }\end{array}$ & Ordinal \\
\hline
\end{tabular}

Sumber: data diolah, 2020

Populasi pada penelitian ini adalah 75 orang auditor dan pengawas Inspektorat. Pengambilan sampel menggunakan sampel jenuh sehingga peneliti menggunakan semua auditor di Inspektorat Daerah Provinsi Gorontalo yaitu 75 orang. Data-data yang telah dikumpulkan kemudian di uji dengan regresi berganda (Multiple Regretion) yang rumusnya dapat disajikan sebagai berikut ini:

$$
Y=a+b_{1} X_{1}+b_{2} X_{2}+e
$$

Keterangan:

$\mathrm{Y}=$ Efektivitas kerja auditor

$\mathrm{a}=$ Konstanta

$\mathrm{X}_{1}=$ Kompetensi

$\mathrm{X}_{2}=$ Independensi

$\mathrm{b}=$ Koefisien Regresi

$\mathrm{e}=$ Kesalahan prediksi

\section{HASIL PENELITIAN}

\section{Penaksiran Model Regresi}

Setelah dilakukan uji asumsi klasik dan ternyata dipenuhi, tahap selanjutnya dilakukan pemodelan data dengan Tabel 1: Definisi Operasional Variabel

\begin{tabular}{|c|c|c|}
\hline Variabel & Indikator & Skala \\
\hline
\end{tabular}
menggunakan analisis regresi berganda. Hasil analisis ditampilkan pada tabel 2 sebagai berikut:

Tabel 2: Hasil Analisis Regresi 


\begin{tabular}{|cc|c|c|c|c|c|}
\hline \multirow{2}{*}{ Model } & \multicolumn{2}{|c|}{$\begin{array}{c}\text { Unstandardized } \\
\text { Coefficients }\end{array}$} & $\begin{array}{c}\text { Standardized } \\
\text { Coefficients }\end{array}$ & \multirow{2}{*}{ t } & \multirow{2}{*}{ Sig. } \\
\cline { 2 - 5 } & B & $\begin{array}{c}\text { Std. } \\
\text { Error }\end{array}$ & Beta & & \\
\hline \multirow{2}{*}{1} & (Constant) & 4.089 & 5.204 & & .786 & .435 \\
& Kompetensi & .257 & .074 & .264 & 3.464 & .001 \\
& Independensi & .678 & .078 & .664 & 8.699 & .000 \\
\hline
\end{tabular}

Sumber: Data olahan SPSS 21, 2020

Berdasarkan hasil analisis di atas, model regresi linear sederhana yang bangun adalah:

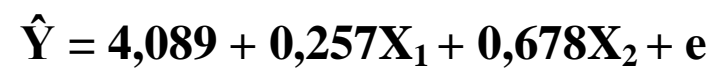

\section{Pengujian Hipotesis}

a. Pengujian Hipotesis Parsial

1) Pengaruh Kompetensi auditor terhadap efektivitas kerja auditor Di Inspektorat Daerah Provinsi Gorontalo

Hasil pengujian pengaruh Kompetensi auditor terhadap efektivitas kerja auditor disajikan dalam tabel berikut ini:

Tabel 3: Hasil Uji Parsial X1 terhadap Y

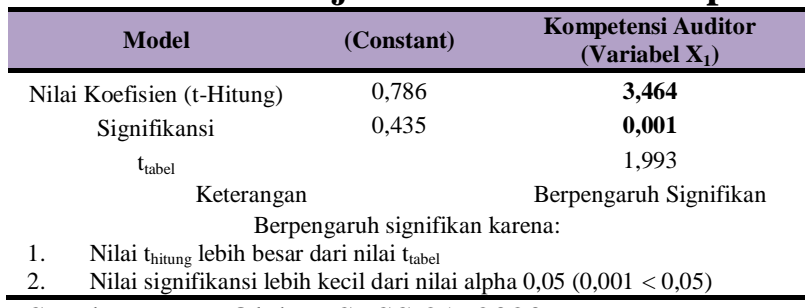

Sumber: Data Olahan SPSS 21, 2020

Hasil analisis diatas

menunjukkan bahwa nilai $\mathrm{t}_{\text {-hitung }}$ untuk variabel Kompetensi auditor diperoleh sebesar 3,464 sedangkan nilai $\mathrm{t}_{\text {-tabel }}$ pada tingkat signfikansi 5\% dan derajat bebas n-k1 atau 75-2-1=72 sebesar 1,993. Jika kedua nilai $\mathrm{t}$ tersebut dibandingkan maka nilai $\mathrm{t}$ hitung masih lebih besar dibandingkan dengan nilai $\mathrm{t}_{\text {-tabel }}(3,464>1,993)$. Maka dari itu disimpulkan bahwa pada tingkat kepercayaan 95\% kompetensi auditor berpengaruh positif dan signifikan terhadap efektivitas kerja auditor di Inspektorat Daerah Provinsi Gorontalo. Makna dari koefisien positif menunjukkan bahwa semakin tinggi kompetensi dari auditor maka akan semakin efektif pula hasil kerja dari auditor di Inspektorat Daerah Provinsi Gorontalo..

\section{2) Pengaruh Independensi auditor terhadap efektivitas kerja auditor Di Inspektorat Daerah Provinsi Gorontalo}

Hasil pengujian tentang pengaruh independensi auditor terhadap efektivitas kerja auditor disajikan dalam tabel berikut:

\begin{tabular}{ccc} 
Tabel 4: Hasil Uji Parsial X2 terhadap Y \\
\hline Model & (Constant) & $\begin{array}{c}\text { Independensi auditor } \\
\text { (Variabel } \mathbf{X}_{2} \text { ) }\end{array}$ \\
\hline Nilai Koefisien (t-Hitung) & 0,786 & $\mathbf{8 , 6 9 9}$ \\
Signifikansi & 0,435 & $\mathbf{0 , 0 0 0}$ \\
ttabel $_{\text {Keterangan }}$ & & 1,993 \\
& & Berpengaruh Signifikan
\end{tabular}

Nilai t lebih berpengaruh signifikan karena:

Nilai signifikansi lebih kecil dari nilai alpha $0,05(0,000<0,05)$ Sumber: Data Olahan SPSS 21, 2020

Hasil analisis diatas menunjukkan bahwa nilai t-hitung untuk variabel Independensi auditor diperoleh sebesar 8,699 sedangkan nilai $t$-tabel pada tingkat signfikansi 5\% dan derajat bebas n-k1 atau $75-2-1=72$ sebesar 1,993 . Jika kedua nilai $\mathrm{t}$ tersebut dibandingkan maka nilai $\mathrm{t}$ hitung masih lebih besar dibandingkan dengan nilai $t_{-t a b e l}(8,699>1,993)$. Maka dari itu disimpulkan bahwa pada tingkat kepercayaan 95\% Independensi auditor berpengaruh positif dan signifikan terhadap efektivitas kerja auditor di Inspektorat Daerah Provinsi Gorontalo. Makna dari koefisien positif menunjukkan bahwa semakin independen seorang auditor dalam melakukan 
pemeriksaan dan fungsi pengawasan fungsionalnya maka efektivitas kerja auditor di Inspektorat Daerah Provinsi Gorontalo akan semakin optimal.

\section{b. Pengujian Hipotesis Simultan}

Adapun hasil Pengujian simultan dalam penelitian ini dapat dilihat pada tabel 5 berikut:

Tabel 5: Hasil Pengujian Simultan

\begin{tabular}{|cc|c|c|c|c|c|}
\hline \multicolumn{1}{|c|}{ Model } & $\begin{array}{c}\text { Sum of } \\
\text { Squares }\end{array}$ & df & $\begin{array}{c}\text { Mean } \\
\text { Square }\end{array}$ & F & Sig. \\
\hline \multirow{2}{*}{ 1 } & Regression & 7764.847 & 2 & 3882.423 & 60.559 & $.000^{6}$ \\
& Residual & 4615.920 & 72 & 64.110 & & \\
\hline & Total & 12380.766 & 74 & & & \\
\hline
\end{tabular}

Sumber: Data Olahan SPSS 21, 2020

Dari tabel di atas didapat nilai $\mathrm{F}_{\text {hitung }}$ penelitian ini sebesar 60,559 . Sementara itu nilai $\mathrm{F}_{\text {tabel }}$ pada tingkat signifikansi $5 \%$ dan df1 sebesar $\mathrm{k}=2$ dan df2 sebesar N-k-1=752-1=72 adalah sebesar 3,124. Jika kedua nilai $\mathrm{F}$ ini dibandingkan, maka nilai $\mathrm{F}_{\text {-hitung }}$ yang diperoleh jauh lebih besar $F_{\text {tabel }}$ sehingga kompetensi auditor dan independensi auditor secara bersama-sama berpengaruh signifikan terhadap efektivitas kerja auditor Di Inspektorat Daerah Provinsi Gorontalo.

\section{Koefisien Determinasi}

Besarnya koefisien determinasi $\left(\mathrm{R}^{2}\right)$ dalam penelitian ini dapat dilihat pada tabel 6 berikut:

Tabel 6: Koefisien Determinasi

\begin{tabular}{|c|c|c|c|c|}
\hline Model & R & R Square & Adjusted R Square & $\begin{array}{c}\text { Std. Error of the } \\
\text { Estimate }\end{array}$ \\
\hline 1 & $.792^{\mathrm{a}}$ & .627 & .617 & 8.00687 \\
\hline
\end{tabular}

Sumber: Data Olahan SPSS 21, 2020

Berdasarkan hasil analisis koefisien determinasi pada tabel di atas maka dapat dilihat bahwa besar pengaruh (kemampuan variabel bebas dalam menjelaskan variabel terikat) menggunakan nilai Adjusted $R$ Square, sebesar 0,617. Nilai ini menunjukkan bahwa sebesar $61,70 \%$ variabilitas efektivitas kerja auditor Di Inspektorat Daerah Provinsi Gorontalo dapat dijelaskan oleh kompetensi auditor dan independensi auditor, sedangkan sisanya sebesar $38,30 \%$ dapat dijelaskan oleh variabel lain yang tidak diteliti dalam penelitian ini. Selanjutnya dilakukan pengujian koefisien parsial. Hasil pengujian untuk koefsien determinasi parsial dijabarkan dalam tabel berikut ini:

Tabel 4.29: Koefisien Determinasi Parsial

\begin{tabular}{|c|c|c|c|}
\hline \multirow{2}{*}{ Model } & \multirow{2}{*}{$\begin{array}{c}\text { Korelasi } \\
(\mathbf{R})\end{array}$} & \multicolumn{2}{|c|}{ Determinasi } \\
\cline { 3 - 4 } & $\mathbf{R}^{\mathbf{2}}$ & $\mathbf{\%}$ \\
\hline Kompetensi auditor & 0.485 & 0.235 & $23,50 \%$ \\
\hline Independensi auditor & 0.752 & 0.566 & $56,60 \%$ \\
\hline
\end{tabular}

Sumber: Data Olahan SPSS 21, 2020

\section{PEMBAHASAN}

1. Pengaruh Kompetensi auditor terhadap efektivitas kerja auditor di Inspektorat Daerah Provinsi Gorontalo

Kompetensi adalah suatu

kemampuan, keahlian (pendidikan dan pelatihan), dan berpengalaman dalam memahami kriteria dan dalam menentukan jumlah bahan bukti yang dibutuhkan untuk dapat mendukung kesimpulan yang akan diambilnya. Hasil analisis deskriptif yakni perbandingan antara skor aktual dengan skor ideal ditemukan bahwa variabel kompetensi auditor terletak pada kriteria yang "kompeten" dengan skor sebesar 79,90\%. 
Kemudian sebanyak 24 orang responden (auditor) atau sebesar 32,00\% yang memiliki kompetensi pada kriteria sangat kompeten, sementara itu sebanyak 47 orang auditor atau sebesar $62,70 \%$ yang memiliki kompetensi auditor kompeten. Serta sebanyak 4 orang auditor atau sebesar 5,30\% yang memiliki kompetensi auditor cukup kompeten.

Hal ini menunjukkan bahwa auditor di Inspektorat Daerah Provinsi Gorontalo memiliki kemampuan yang baik berupa pengetahuan dan keterampilan yang dapat digunakan untuk memaksimalkan hasil kerjanya terkait dengan audit dengan tata administrasi dan pengelolaan keuangan pada Pemerintah Provinsi Gorontalo. Auditor yang kompeten akan mampu untuk melakukan suatu pekerjaan sesuai dengan target kualitas, kuantitas dan pemanfaatan waktu yang diberikan dalam pelaksanaan pemeriksaan dan pengawasan fungsional terhadap instansi di lingkungan Provinsi Gorontalo karena dengan adanya kompetensi maka pengambilan keputusan untuk rekomendasi hasil audit akan sesuai dengan fakta di lapangan. Hal ini dipertegas oleh pernyataan dari Hasibuan dalam Sulila (2019) bahwa kompetensi adalah karakteristik mendasar dari seseorang yang terkait dengan efektivitas kinerja individu dalam pekerjaan. Hal ini menunjukan bahwa seorang auditor apabila memiliki kompetensi yang mumpuni maka akan berdampak pada hasil pekerjaan yang sesuai dengan target kerja yang ditetapkan.

Hasil pengujian hipotesis pertama melalui uji regresi berganda ditemukan bahwa kompetensi auditor berpengaruh positif dan signifikan terhadap efektivitas kerja auditor di Inspektorat Daerah Provinsi Gorontalo dengan nilai determinan sebesar 23,50\%. Makna dari koefisien positif menunjukkan bahwa semakin tinggi kompetensi dari auditor maka akan semakin efektif pula hasil kerja dari auditor di Inspektorat Daerah Provinsi Gorontalo. Sementara itu, sel dalam tabulasi silang didominasi oleh auditor yang memiliki kompetensi auditor berada pada kriteria kompeten kemudian memiliki hasil kerja yang efektif yakni sebanyak 38 orang yang menunjukkan bahwa adanya pengaruh yang baik dari kompetensi auditor dalam menjadikan auditor memiliki hasil capaian kerja yang lebih optimal.

Kompetensi auditor meskipun hasilnya signifikan melalui uji tuckey (uji t) namun melihat nilai determinan masih harus ditingkatkan. Hal ini karena kompetensi auditor dalam penelitian ini diukur dari aspek yang nampak (kecerdasan intelektual) sedangkan aspek yang tidak nampak yakni kecerdasan emosional dan spiritual sulit untuk diukur sehingga hasilnya tidak begitu kuat dampaknya bagi efektivitas kerja. Hal ini sebagaimana menurut Abdussamad (2014:95) bahwa kompetensi meliputi dalam 
dua tingkatan yakni ada yang tampak dan yang tidak tampak. Ketika seluruh aspek kompetensi dioptimalkan maka dampaknya pada hasil kerja yang berkualitas dan efektif.

Hasil ini sejalan dengan pernyataan dari Kharismatuti dan Hadiprajitno (2012:33) bahwa kompetensi sebagai keahlian yang cukup yang secara eksplisit dapat digunakan untuk melakukan audit secara objektif.

\section{Pengaruh Independensi auditor terhadap efektivitas kerja auditor di Inspektorat Daerah Provinsi Gorontalo}

Hasil analisis deskriptif yakni perbandingan antara skor aktual dengan skor ideal ditemukan bahwa variabel independensi auditor terletak pada kriteria yang "independen" dengan skor sebesar 80,27\%. Kemudian sebanyak 23 orang responden (auditor) atau sebesar 30,70\% yang sangat independen sementara itu sebanyak 49 orang auditor atau sebesar $65,30 \%$ yang independen. Serta sebanyak 3 orang auditor atau sebesar $4,00 \%$ yang cukup independen dalam mengemban tanggung jawab yang diamanahkan. Hal ini menunjukkan bahwa auditor di Inspektorat Daerah Provinsi Gorontalo memiliki sikap independen yang baik yang tidak tergoyahkan dalam melakukan tugas dan tanggung jawabnya sebagai seorang auditor internal pada pemerintahan di Provinsi Gorontalo. Sikap independen ditunjukkan oleh auditor dengan tegas terhadap temuan- temuan yang harus diperbaiki atau dibenahi oleh instansi (SKPD) terkait dengan sistem pengendalian intern, tata kelola keuangan maupun teknis dan administrasi pelayanan publik. Sikap independen ini terus dijaga oleh auditor agar mampu bekerja sesuai dengan kode etiknya sehingga hasil audit benar-benar efektif sebagai ukuran capaian kerja dari auditor di Inspektorat Daerah Provinsi Gorontalo.

Faktor yang mempengaruhi kualitas audit adalah ketaatan auditor terhadap kode etik yang terefleksikan oleh sikap independensi, objektifitas dan integritas. Hal ini menunjukkan bahwa sikap dari seorang pelaksana atau pegawai dalam lingkungan pemerintahan akan menentukan bagaimana efektivitasnya dalam menjalankan tugas dan tanggung jawabnya. Hal ini dipertegas dengan pernyataan dari Sulila (2019) bahwa sikap dari pelaksana menjadi aspek yang krusial dalam mempengaruhi suatu program atau implementasinya dimana salah satu program tersebut yakni melakukan audit atau pemeriksaan atau tata kelola administrasi dan keuangan pada pemerintah Provinsi Gorontalo. Sikap pelaksana dalam hal sikap independen ini akan membuat hasil audit menjadi berkualitas sehingga menjadi tanda bahwa baiknya hasil kerja auditor atau efektifnya proses dan hasil kerja auditor dengan perencanaan yang ditetapkan.

Hasil pengujian hipotesis kedua melalui uji regresi berganda ditemukan 
bahwa independensi auditor berpengaruh positif dan signifikan terhadap efektivitas kerja auditor di Inspektorat Daerah Provinsi Gorontalo dengan nilai determinan sebesar 56,60\%. Makna dari koefisien positif menunjukkan bahwa semakin independen seorang auditor dalam melakukan pemeriksaan dan fungsi pengawasan fungsionalnya maka efektivitas kerja auditor di Inspektorat Daerah Provinsi Gorontalo akan semakin optimal. Sementara itu, sel dalam tabulasi silang didominasi oleh auditor yang independen dalam menjalankan tanggung jawabnya kemudian mampu mencapai hasil kerja yang efektif sebanyak 39 orang. Hal ini menunjukkan bahwa independensi mampu memberikan kontribusi yang baik dalam mengupayakan adanya hasil kerja auditor di di Inspektorat Daerah Provinsi Gorontalo yang semakin efektif.

Secara keseluruhan maka hasil penelitian ini sejalan dengan pernyataan dari Menurut Winda dan Sofie (2014) pengaruh independensi terhadap kualitas audit yakni independensi merupakan sikap auditor yang tidak memihak, tidak mempunyai kepentingan pribadi, dan tidak mudah dipengaruhi oleh pihak-pihak yang berkepentingan dalam memberikan pendapat.

3. Pengaruh Kompetensi auditor dan Independensi auditor Secara Simultan terhadap efektivitas kerja auditor di Inspektorat Daerah Provinsi Gorontalo
Hasil analisis deskriptif yakni perbandingan antara skor aktual dengan skor ideal ditemukan bahwa variabel efektivitas kerja auditor terletak pada kriteria yang efektif dengan skor 79,48\%. Kemudian sebanyak 17 orang responden (auditor) atau sebesar $22,70 \%$ yang sangat efektif dalam bekerja sementara itu sebanyak 56 orang auditor atau sebesar $74,70 \%$ yang efektif dalam bekerja. Serta sebanyak 2 orang auditor atau sebesar 2,70\% yang cukup efektif dalam menjalankan tugasnya sebagai auditor internal pada pemerintah Provinsi Gorontalo.

Hal ini menunjukkan bahwa auditor di Inspektorat Daerah Provinsi Gorontalo mmapu mencapai hasil kerja aktual yang sesuai dengan target atau perencanaan kerja yang dilakukan. Adanya kecenderungan pencapain target kerja yang sesuai ini akan berimbas pada hasil kerja dan pencapaian visi misi instansi yang semakin mudah digapai. Auditor yang mampu bekerja dengan efektif menandakan bahwa auditor itu telah mengoptimalkan segenap potensi dalam dirinya baik itu yang berhubungan kemampuan intelektualnya dan keterampilan yang dalam hal ini digambarkan sebagai suatu kompetensi dan juga mampu mengoptimalkan hal-hal dalam diri yang berkaitan dengan sikap independen sehingga mampu bekrja secara profesional sebagai auditor internal dalam menciptakan tata kelola pemerintahan yang baik. 
Efektivitas kerja dari aduitor ini yakni untuk memperbaiki pengelolaan keuangan dari pemerintah daerah. Pentingnya pengelolaan keuangan daerah untuk terus dipantau dan dilakukan pemeriksaan sebagaimana menurut Sulila (2019) yakni pengelolaan keuangan daerah adalah suatu upaya untuk menemukan sumber daya pendanaan daerah dengan mencari potensi terstruktur dan kemampuan daerah. Auditor internal harus menilai pekerjaan, operasi atau program untuk menilai apakah hasil yang dicapai telah sesuai dengan tujuan dan sasaran yang telah ditetapkan dan apakah pekerjaan operasi atau program tersebut telah dilaksanakan sesuai dengan rencana. Kesesuaian antara rencana dengan hasil dapat dicapai dengan optimalnya kompetensi dari auditor dan sikap independen dari auditor tersebut

Hasil pengujian hipotesis ketiga melalui uji regresi berganda ditemukan bahwa kompetensi auditor dan independensi auditor secara bersama-sama berpengaruh signifikan terhadap efektivitas kerja auditor di Inspektorat Daerah Provinsi Gorontalo dengan nilai determinan sebesar $61,70 \%$, sedangkan sisanya sebesar $38,30 \%$ dapat dijelaskan oleh variabel lain seperti variabel pendidikan auditor, integritas auditor, motivasi kerja auditor, disiplin kerja serta sikap profesional auditor. Jika kompetensi auditor dibarengi dengan sikap independen maka efektivitas kerja auditor di Inspektorat
Daerah Provinsi Gorontalo akan sesuai dengan harapan dari auditor itu sendiri maupun pimpinan instansi. Sehingga Hasil ini sesuai dengan pernyataan dari Elfarini (2007) dan Justinia (2008) juga menunjukkan bahwa kompetensi dan independensi secara simultan berpengaruh terhadap kualitas audit.

\section{SIMPULAN}

Berdasarkan hasil penelitian dan pembahasan pada bab sebelumnya, maka dapat ditarik beberapa simpulan penelitian sebagai berikut:

1. Kompetensi auditor berpengaruh positif dan signifikan terhadap efektivitas kerja auditor di Inspektorat Daerah Provinsi Gorontalo dengan nilai determinan sebesar 23,50\%. Makna dari koefisien positif menunjukkan bahwa semakin tinggi kompetensi dari auditor maka akan semakin efektif pula hasil kerja dari auditor di Inspektorat Daerah Provinsi Gorontalo.

2. Independensi auditor berpengaruh positif dan signifikan terhadap efektivitas kerja auditor di Inspektorat Daerah Provinsi Gorontalo dengan nilai determinan sebesar 56,60\%. Makna dari koefisien positif menunjukkan bahwa semakin independen seorang auditor dalam melakukan pemeriksaan dan fungsi pengawasan fungsionalnya maka efektivitas kerja auditor di Inspektorat 
Daerah Provinsi Gorontalo akan semakin optimal.

3. Kompetensi auditor dan independensi auditor secara bersama-sama berpengaruh signifikan terhadap efektivitas kerja auditor di Inspektorat Daerah Provinsi Gorontalo dengan nilai determinan sebesar $61,70 \%$, sedangkan sisanya sebesar $38,30 \%$ dapat dijelaskan oleh variabel lain seperti variabel pendidikan auditor, integritas auditor, motivasi kerja auditor, disiplin kerja serta sikap profesional auditor.

\section{SARAN}

Berdasarkan hasil penelitian dan simpulan penelitian, maka saran penelitian ini adalah sebagai berikut:

1. Sebaiknya pihak inpektorat Inspektorat Daerah Provinsi Gorontalo aktif dalam mengikuti pelatihan yang dapat menambah wawasan dalam melakukan audit. Dalam melakukan atau mengikuti pelatihan sebaiknya dilakukan dengan sungguh-sungguh agar hasilnya menjadi lebih bermakna bagi perkembangan pengetahuan dan kompetensi dari auditor internal.

2. Sebaiknya para auditor internal menjaga sikapnya dengan cara berkomitmen tinggi yang dibuktikan dengan kemampuan untuk mengungkapkan temuan meskipun temuan tersebut dilakukan oleh seseorang yang menjadi kolega dari auditor internal pemerintahan di Provinsi Gorontalo.

3. Sebaiknya pihak auditor internal terus memberikan dan melakukan pemeriksaan dengan sebaik mungkin. Kemudian pimpinan dalam mengalokasikan waktu untuk tugas para auditor memperhatikan trend penyelesaian tugas pada periode sebelumnya. Cara yang dapat dilakukan oleh pimpinan yakni dengan mengalokasikan auditor lainnya yang sudah selesai tugasnya membantu yang belum selesai namun bukan pada hal teknis di lapangan.

\section{BAB V \\ PENUTUP}

\section{A. Simpulan}

Berdasarkan hasil penelitian dan pembahasan pada bab sebelumnya, maka dapat ditarik beberapa simpulan penelitian sebagai berikut:

4. Kompetensi auditor berpengaruh positif dan signifikan terhadap efektivitas kerja auditor di Inspektorat Daerah Provinsi Gorontalo dengan nilai determinan sebesar 23,50\%. Makna dari koefisien positif menunjukkan bahwa semakin 
tinggi kompetensi dari auditor maka akan semakin efektif pula hasil kerja dari auditor di Inspektorat Daerah Provinsi

\section{Gorontalo.}

5. Independensi auditor berpengaruh positif dan signifikan terhadap efektivitas kerja auditor di Inspektorat Daerah Provinsi Gorontalo dengan nilai determinan sebesar 56,60\%. Makna dari koefisien positif menunjukkan bahwa semakin independen seorang auditor dalam melakukan pemeriksaan dan fungsi pengawasan fungsionalnya maka efektivitas kerja auditor di Inspektorat Daerah Provinsi Gorontalo akan semakin optimal.

6. Kompetensi auditor dan independensi auditor secara bersama-sama berpengaruh signifikan terhadap efektivitas kerja auditor di Inspektorat Daerah Provinsi Gorontalo dengan nilai determinan sebesar $61,70 \%$, sedangkan sisanya sebesar $38,30 \%$ dapat dijelaskan oleh variabel lain seperti variabel pendidikan auditor, integritas auditor,

motivasi kerja auditor, disiplin kerja serta sikap profesional auditor.

\section{B. Implikasi}

Berdasarkan simpulan penelitian maka implikasi dalam penelitian ini, dapat dijabarkan sebagai berikut:

1. Jika kompetensi auditor meningkat maka efektivitas kerja auditor di Inspektorat Daerah Provinsi Gorontalo juga akan mengalami peningkatan untuk pencapaian visi dan misi instansi.

2. Jika auditor semakin independen maka hasil kerja kerja auditor di Inspektorat Daerah Provinsi Gorontalo akan semakin efektif sesuai dengan perencanaan kerja.

3. Jika kompetensi auditor dibarengi dengan sikap independen maka efektivitas kerja auditor di Inspektorat Daerah Provinsi Gorontalo akan sesuai dengan harapan dari auditor itu sendiri maupun pimpinan instansi.

\section{Saran}


Berdasarkan hasil penelitian dan simpulan penelitian, maka saran penelitian ini adalah sebagai berikut:

1. Sebaiknya pihak inpektorat Inspektorat Daerah Provinsi Gorontalo aktif dalam mengikuti pelatihan yang dapat menambah wawasan dalam melakukan audit. Dalam melakukan atau mengikuti pelatihan sebaiknya dilakukan dengan sungguh-sungguh agar hasilnya menjadi lebih bermakna bagi perkembangan pengetahuan dan kompetensi dari auditor internal.

2. Sebaiknya para auditor internal menjaga sikapnya dengan cara berkomitmen tinggi yang dibuktikan dengan kemampuan untuk mengungkapkan temuan meskipun temuan tersebut dilakukan oleh seseorang yang menjadi kolega dari auditor internal pemerintahan di Provinsi Gorontalo.

3. Sebaiknya pihak auditor internal terus memberikan dan melakukan pemeriksaan dengan sebaik mungkin. Kemudian pimpinan dalam mengalokasikan waktu untuk tugas para auditor memperhatikan trend penyelesaian tugas pada periode sebelumnya. Cara yang dapat dilakukan oleh pimpinan yakni dengan mengalokasikan auditor lainnya yang sudah selesai tugasnya membantu yang belum selesai namun bukan pada hal teknis di lapangan.

\section{DAFTAR PUSTAKA}

Abdussamad, Zuchri. 2014. Kompetensi Aparat Dalam Pelayanan Publik. Gorontalo: Deepublish.

Arens, Alvin A., Elder, dan Beasley. 2008. Auditing dan Jasa Assurance. Pendekatan Terintegrasi Jilid 1. Edisi 12. Jakarta: Erlangga.

Bouhawia, Mohammed.S; Gugus Irianto and Zaki Baridwan. 2015. The Effect of Working Experience, Integrity, Competence, and Organizational Commitment on Audit Quality (Survey State Owned Companies In Libya). IOSR Journal of Economics and Finance (IOSR-JEF) e-ISSN: 23215933, p-ISSN: 2321-5925.Volume 6, Issue 4. Ver. II (Jul. - Aug. 2015), PP 60-67 www.iosrjournals.org

Christiawan, Yulius Jogi. 2003. Kompetensi dan independensi akuntan publik : refleksi hasil penelitian empiris. Jurnal Akuntansi dan Keuangan, Vol.4, (No.2).

Elfarini, E.C. 2008. Pengaruh Kompetensi dan Independensi Auditor terhadap Kualitas Audit. Jurnal. Universitas Negeri Semarang 
Harhinto, Teguh 2004. Pengaruh Keahlian dan Independensi Terhadap Kualitas Audit Studi Empiris Pada KAP di Jawa Timur. Semarang: Tesis Maksi Universitas Diponegoro.

Justinia, Castellani. 2008. Kompetensi dan Independensi Auditor Pengaruhnya pada Kualitas Audit. Jurnal Trikonomika, Vol 7, No. 2, Desember 2008:114:121

Kharismatuti, Norma dan P. Basuki Hadiprajitno. 2012. "Pengaruh Kompetensi dan Independensi terhadap Kualitas Audit dengan Etika Auditor sebagai Variabel Moderasi" (Studi Empiris pada Internal Auditor BPKP DKI Jakarta). Diponegoro Journal of Accounting Vol.1 No.1 Hal 1-10

Mardiasmo. 2012. Akuntansi Sektor Publik. Yogyakarta: Penerbit Andi.

Sulila, Ismet. 2019. Regional Financial Public Services Evaluation Based on Regional Budget and Expenditure. Jurnal Sosial dan Pembangunan MIMBAR. Volume 35 Nomor 2. Page 295-305 Print ISSN: 0215-8175; Online ISSN: 2303-2499.

DOI: https://doi.org/10.29313/mimbar.v3 $\underline{5 \mathrm{i} 2.4674}$

Sulila, Ismet. 2019. An Analysis of the Effectiveness of Allocation of Village Fund Policy Implementation and Its Determining Factors in Gorontalo Regency. Jurnal Ilmiah Ilmu Administrasi Publik: Jurnal Pemikiran dan Penelitian Administrasi Publik Volume 9 Number 2, July- December 2019. Page 67-78 p-ISSN: 2086-6364, eISSN: 2549-7499. DOI: https://doi.org/10.26858/jiap.v9i2.1 0947

Sulila, Ismet. 2019. The Effect of Human Resource Competency and
Implementation of SIMDA on the Quality of Financial Statement at BPKAD Office of Gorontalo City. Jurnal Publik (Jurnal Ilmu Administrasi). Volume 8 Nomor 1. Page 67-74. ISSN: 2301-573X (Print), ISSN: 2581-2084 (Online). DOI:

http://dx.doi.org/10.31314/pjia.8.1.6 7-74.2019

Winda, Khomsiyah dan Sofie. 2014. Pengaruh Kompetensi, Independensi, Tekanan Waktu, dan Etika Auditor Terhadap Kualitas Audit. E-Jurnal Akuntansi Fakultas Ekonomi. Universitas Trisakti. Volume 1 Nomor 2 September 2014. Hal. 49-67. ISSN:2339-0832. 